\title{
Intersecting Islamic and Chinese Cultural Values as A Modal of Production of Assalamualaikum Beijing Novel Written by Asma Nadia
}

\author{
Helius Udaya ${ }^{1}$, Emzir $^{2}$, Aceng Rahmat ${ }^{3}$ \\ \{heliusudaya@unj.ac.id\} \\ ${ }^{123}$ Universitas Dayanu Ikhsanuddin Baubau, Sulawesi Tenggara, Indonesia
}

\begin{abstract}
Islamic-themed novel in the twenty first century got its spirit in the production of Indonesian popular literature. This study purposed to dsection of Islamic and Chinese cultural values in Assalamualaikum Beijing novel written by Asma Nadia. Theory that used in this study was sosiologi of literature proposed by Pierre Bourdieu and data analyzed through descriptevelyinterpretive way. This study found that Asma Nadia as a writer of this novel is intersecting Islamic and Chinese cultural atrributes in the novel Assalamualaikum Beijing by ,first, presenting the new formula of protagist character. Chinese male character as protaginist and Indonesian muslim male character as antagonist. Second, presenting intercultural interaction through chinese and indonesia muslim people to assert that life is inclusive and the culture can be intersected each other. Intersection process then is just merely a strategic and positional than essential towards a difference among communities. The intersection of Islam and Chinese cultural values in this novel can not take apart from the habitus of the author. Asma Nadia as the author of the novel is Indonesian born Chinese person. It seems that, through this novel, the author creates a distinction by intersecting Indonesian-Islamic values to specify herself as Islamic genre writer with global mindset. This is become the hallmark of the novel that posited Asma Nadia in the midst of the contestation of Indonesia literature and lead to the commercial profit.
\end{abstract}

Keywords- Chinese, Modal, Culture, Islamic, Intersection

\section{Introduction}

In the twenty-first century, Indonesian literature was revived by the publication of Islamicthemed novels. These novels not only enlivened the genre of Islamic literature with their innovations, but also formed a class with collective identity codes. According to [1] a class as a collective identity is formed by many social codes depending on the form of loyalty, commitment, attributes (ascription) and affiliation that determine them: language, religion, ideology [1]. [1] also adds that clothing, fashion, and tastes are codes that bind "members" and bring group symbols into a collective identity. Collective identity is formed by some class code. 
Since the 1980s in Indonesia, broad channels of expression as complementary codes have formed a new social class, namely awareness as a 'Muslim middle class.' The code goes beyond mere political and economic codes, namely cultural codes.

The above phenomenon apparently also reflected in the production of literature. The description of the rise of Islamic themes in the landmark of literature can be seen in popular Indonesian novels in contemporary era. In the midst of stretching world literature that developed and influenced Indonesian literature, popular Islamic-themed novels appeared in different colors. The names of writers such as Habiburahman El Sherazy, Hanum Rais, and Asma Nadia are writers who oversee the production of popular Islamic-themed novels in the contemporary era with a variety of themes.

[2] has a unique formula when presenting Islamic-based stories. She combines Islamic with Chinese cultural values which is in reality are often disputed. Islam is identical with its ideology which emphasizes almighty divine values, while China is identical with communist ideology that posited material as forces production. This novel also reaped popularity and became a best seller. The intersection of Islamic and Chinese cultural values that were built harmoniously in the novel seems to be an appeal of the story that is so compelling to be read in the contemporary era. The popularity of this novel is then seen in its transformation into a film that follows in the footsteps of the novel, the bestseller and is loved by audiences of all ages.

Researches about Islamic cultural attribute in present literature has discussed by many scholars with different focus and nations. [3] investigated about muslim identity in the latest American Comics' Ms. Marvel. Marvel Comics released a new series in early 2014 whose the main character a Pakistani-American Muslim girl named Kamala Khan. The story is a breakthrough against the negative representation of Islam in the Western world, especially after 9/11. Paramitha stated MS Marvel comic is the representation of American Muslim immigrant that to survive in the American environment, they must adopt a pluralistic identity, which enable them to switch between the two identities as Muslim and American. In the other side, American society itself has also changed and begun to adapt to the idea that Muslim immigrants are members of their community. [4] analyzed intertextual and educational values in the novel Ayat-Ayat Cinta by Habiburrahman El Shirazy and the Kasidah-Cinta by Muhammad Muhyidin. [5] discussed the construction of Islam as a symbol of identity through the representation of Muslim women in religious novels entitled Ratu yang Bersujud. [6] is talking about contemporary Muslim female writers and the representation of the identity and religion of Muslim women in Indonesian fiction. Specializes in the discussion of one genre of literature born in Indonesia, pesantren literature.

The analysis of this study is predicated with the belief that if the Islamic themed novels are written in the 21 st century by Asma Nadia, she should have a new insight about Islamic values and global mindset. So, this paper intended to describe how Islamic attributes are used as capital in the creation of the Assalamualaikum Beijing novel. Through the disclosure of this problem it is expected to show how the mental structure that surrounds Asma Nadia becomes a modal in the Assalamualaikum Beijing novel.

Mental structure is related to Bourdieu's theory about habitus. According to [7] the literary arena is an arena for agent struggles for position and legitimacy. Each agent has a different accumulation of capital and habitus [8]. Pierre Bourdieu explained the route of agent struggle in certain social spaces and arenas as a specific part of social space in his concept of the trajectory or trajectory or biography constructed. [9] believes that the analysis of literature or art is to carry out jointly with internal and external analysis which, in Pierre Bourdieu's language, must consider the social conditions of production. The literary arena is a complexity which contains a series of practices: conflict, competition and control involving literary agents. This research 
then looks at how Islam not only became a commodity product to gain profits but also to create a class in Indonesian literature. This relates to the habitus that influenced the production process of the novel that raised Islam. Habitus is a subjective structure that is formed from the experience of the individual author related to other individuals in a network of objective structures that are in social space. Habitus may be said as a cultural unconscious, namely history that is unconsciously considered natural, which is formed from the results of learning through nurturing, play activities, and also public education in a broad sense [10]. This habitus then became the capital of literary works to enter the world of literary contestation.

Data in this study text of novel Assalamualaikum Beijing which published in 2014. Data collected through cataloging and then analyzed descriptive-interpretive way by approaching Pierre Bourdieu's sociology approach. It is emphasized on habitus as capital in the creation of the Beijing Assalamualaikum Beijing Novel.

\section{Results and Discussion}

\subsection{Habitus of Novel Assalamualaikum Beijing}

The Assalamualaikum Beijing, based on Bourdieu's theory, can be said as a constructive structure built by Asma Nadia as a writer to win her position in the literary field. He absorbed the formula of the Islamic novel genre with the conventions and innovations that emerged in the novel. The novel as a constructive structure or social practice is surrounded by habitus that underlies the creation of the novel. Habitus is a mental or cognitive structure with which people relate to the social world. People are equipped with a series of internalization themes that they use to perceive, understand, appreciate, and evaluate the social world. According to [11] habitus is dialectically a product of the internalization of the structure of the social world, so that it is obtained as a result of its position in the social world for a long time [12].

Habitus that shapes and influences the constructive structure built in the Assalamualaikum Beijing novel is not separated from the author's own background. Asma Nadia, the woman who born in 1972 came from mix blood ancestor. Her father, Amin Usman, is from Aceh and her mother, Maria Erie Susanti, is a female convert of Chinese descent from Medan. The combination of two cultures and blood in Asma Nadia's self has shaped her mindset and became the habitus of the Assalamualaikum Beijing novel. The title of this novel reinforces the habitus, Assalamualaikum is a form of greeting for Muslin people, while Beijing is the capital of the People's Republic of Tiongkok. The title marks the intersection of these two cultural values which later became a capital not only seizing a position in the contestation of Indonesian literature but also in gaining the popularity of the work.

In the Indonesian literature, Asma Nadia is posited as an Islamic genre writer. In contrast to other ones, Asma raised the theme of Islam with a unique composition by combining Islamic values with communism. Asma Nadia's mindset shaped by Islamic thought that promotes religious morality is a habitus that is formed from her family background. This can be seen in describing the situation of male infidelity named Dewa with his partner, does not specifically describe the vulgarity aspects of language in describing the sex sense. Asma Nadia explores more about the hymn behind every event featured in the novel.

Habitus formed by family background of Asma Nadia also had an impact on the image of the Chinese culture in this novel. Asma seems to know the slanted issues that occur in Indonesian society that always highlights China as a carrier of communist ideology that is very 
contrary to Islamic ideology. In this novel, Asma Nadia actually promotes harmony between the two ideologies, one of them by elevating the legend of Ashima with Ahey, which was later adapted for the mention of Asma and equating the love story of cultural differences between the main female characters named Asma and Chinese men named Zhongwen. This is the additional value in this novel. She is able to build diplomacy between the two cultures which had always been contested. Such formulas in the Assalamualaikum Beijing novel later became capital in the contestation both in gaining popularity and position in Indonesian literature.

\subsection{Intersection of Cultural Values in the Structure of the Novel}

As explained above, the Islamic habitus formed from the background of the Asma Nadia family has become a capital in the production of the Assalamualaikum Beijing novel. The author has a special strategy when bringing it in the realm of literary creation. There are at least two strategies pursued by author. The first can be seen from the protagonistic and antagonistic formulas, the second is the intersection of Islamic, Chinese and Javanese cultures.

The theme of the Assalamualaikum Beijing novel by Asma Nadia is a process of finding true love. The process of finding true love is displayed through the main character of a Javanese woman named Asmara or commonly called Asma who establish love with a Javanese man named Dewa. In her journey, it turned out that Dewa known as a native man betrayed by having an affair with another woman named Anita, and ended by her pregnancy out of wedlock. The scene can be seen in the following excerpt.

Pemuda yang dikira akan mengiringi langkahnya ke pelaminan, ternyata harus menjauh dari hidupnya. Padahal undangan sudah siap disebar...dia telah salah memilih seseorang untuk menggenggam sebagian hatinya. Hari saat Dewa menceritakan dengan jujur apa yang telah dilakukannya (bersma Anita) benar-benar menghancurkan kepercayaan gadis itu tentang cinta [2].

Dewa as the representation of Muslim and native Indonesian man depicted as a bertrayer, traitor, can't be trusted, and seem easily seduced by women. It is very contrasting with Zhongwen, a Chinesse man character that Asma met in Beijing during vacation and work. The following excerpt displays the character of Zhongwen.

Kesabaran dan kesungguhan Zhongwen merawat Asma menyentuh dan menumbuhkan kembali perasaan sayang dan cinta yang awalnya ikut hilang bersama memori perempuan muda itu. ...Asma merencanakan sebuah kejutan sebagai balasan atas kebaikan lelaki itu mendampinginya. "chinese people can also be very romantic you know" [2].

The brief explanation above shows that, the author tried to build the protagonist formula in the novel, namely Ashma and Chinese man named Zhongwen. Zhongwen is shown as a real man who is responsible to his couple. His image becomes perfect when he was was converting his faith to Islam by studying Islam deeply. This is inversely proportional to Dewa, a Muslim male. He is depicted doing adultery and not fully responsible after he married his adultery girl. From this, it appears that the author tried to present a new formula for the protagonist and antagonist characters. It is the Chinese men is a protagonist character while native Indonesiam man as antagogist character. However, Islam values keept sounding in this novel. the convertion of Zhongwen faith from Konfuchu to Islam signified that the author keep sounding Islam as the way of life in her novel.

Assalamualaikum Beijing novel also inspects the cultural values of Islam-Indonesia and China. In showing the Islamic values can be denoted through the search for Niujie Mosque, one of the oldest mosques in the Xuanwu District, and the Xi'an Grand Mosque in China. It is revealed in the novel that: 
Suatu hari, di pelataran Masjid Niujie, disaksikan banyak orang. Seorang bapak dan ibu tua menyatakan masuk Islam. Keduannya mengucapkan kalimat dalam bahasa Arab dengan terpatah-patah. Ada ketulusan dan kesungguhan dari adegan sederhana, tetapi entah bagaimana begitu menyentuh ruang batin Zongwen [2].

The quote signifies the life of Islam in China through the symbol of Masjid Niujie. Islam is not only belonged to Arab society nor Indonesia and not identical to Arab instead of it is born there. Islam has been a way life of all people in the rest of the world. This is strenghtening by exerpt of the Legend of Meng Jiang Nv in the ancient Kindom of China. The main character of the novel Asma tried to adapt her feeling as the character feeling in the legend.

Allah..Inikah kerinduan, yang dirasakan Meng Jiang Nv, saat suami terkasih, Fn Xi Liang dibawa pergi secara paksa? Air mata tiga hari tiga malam yang mengguncangkan syurga, membuat langit mendadak geap dan angin bertiup kencang. Merubuhkan suatu bagian dari the Great Wall yang sedang dibangun Dinasti Qin Shi. Selain kisah Ashima, Asma tak bosan bosannya mengulang The Legend of Meng Jiang $N v$ [2].

In the other side, the novel also represents Javanese local culture through primbon to signify that though most javanese people in Indonesia conveyed themselves as Islam, they also have traditional faith.

Pasaran Jawa. Tetap ibunya belum berubah. Sebelumnya terkait pemilihan jurusan kuliah, bahkan dalam hal pekerjaan pun, ibu tetap menghitung kelahiran dan kemudian mengelompokkan, mengacu pada primbon. Tidak praktis tetapi Anita tidak bisa melawan [2]

The quote insisted that life is inclusive and the culture can be intersected each other. [13] called it as negotiation process that is a process of transactional interaction in which individuals in an intercultural situation try to impose, define, change, challenge, and / or support the desired self-image on themselves or others. This transactional interaction process according to [14] then has an impact on the difference between one community and another and it is only strategic and positional and not essential. So, it can be said that the intersection of Islam and Chinese cultural values in novel Assalamualaikum Beijing is a representation of intercultural interaction that used to be occured in different comunnity. Asma Nadia as the author of the novel tries to build a strategy in positioning the characters of the novel in intercultural situation to lead to harmonius and worthwide life.

\section{Conclusion}

This paper may conclude that the the intersection of Islam and Chinese cultural values in Assalamualaikum Beijing novel written by Asma Nadia is denoted through, first, the formula of protagonist and antagonist of the novel. It presents Chinese man as the protagonist character and Indonesia Muslim man as the antagonist. It seems able to bring down the sentiment of chine in Indonesia. Second, interaction process in intercultural communication among Muslim and Chinese asserted about life is inclusive and the culture can be intersected each other. It leads to the impact of a difference among one community and the others is merely strategic and positional, and not essential.

The intersection of Islam and Chinese cultural values in this novel is basically stirred by the habitus of the author. Asma Nadia as the author of the novel is Indonesian born Chinese person. She is the descendants of Tionghoa-converted Muslim from Medan and Aceh. The attributes of Islam and Chinese became the capital of creation not only to seize a position in the Indonesian literary contestation and to gain commercial profit, but also to promote the intercultural 
interaction, especially among Chinese people and Indonesian Muslims. She then costumes the structure of the story in the novel by promoting the harmonization of the two ideological settings through the character Asma as Indonesia Muslim woman and Zhongwen Chinese man with its attributes.

\section{References}

[1] A. Rao, "The Many Sources of Identity: An Example of Changing Affiliations in Rural Jammu and Kashmir," Ethn. Racial Stud., vol. 22, no. 1, 1999.

[2] A. Nadia, Assalamualaikum Beijing: A Novel. Depok: AsmaNadia Publishing House, 2013.

[3] P. P. A, "A Representation of the Muslim Immigrant's Identity: A Study of Marvel Comics' MS. Marvel," Gadjah Mada University, 2015.

[4] Wulandari, Mujiyanto, and Hastuti, "Novel Ayat-Ayat Cinta Karya Habiburrahman El Shirazy Dan Novel Kasidahkasidah Cinta Karya Muhammad Muhyidin (Kajian Intertekstual dan Nilai Pendidikan)," BASASTRA J. Penelit. Bahasa, Sastra Indones. dan Pengajarannya, vol. 1, no. 3, pp. 562-572, 2014.

[5] N. Husnan, R. Uliviana, and T. K. B, "Konstruksi Islam sebagai Simbol Identitas melalui Representasi Perempuan Muslim pada Novel Religi,” J. Ilmu Dakwah Acad. J. Homilet. Stud., vol. 12, no. 1, pp. 61-81, 2018.

[6] D. . Arimbi, Reading Contemporary Indonesian Muslim Women Writers: Representation, Identity and Religion of Muslim Women in Indonesian Fiction. Amsterdam: Amsterdam University Press, 2009.

[7] P. Bourdieu, Arena Produksi Kultural (Translation). Jogjakarta: Pustaka Pelajar, 2010.

[8] P. Bordieu, The Field of Cultural Production: Essays on Art and Literature. Cambridge: Polity P. 2. Jenkins, Richard. 1992. Pierre Bourdieu. New York: Routledge, 1993.

[9] P. Bourdeu, Arena Produksi Kultural: Sebuah Kajian Sosiologi Budaya. Yogyakarta: Kreasi Wacana, 2010.

[10] P. Bourdieu, Distinction: A Social Critique of The Judgement of Taste. Cambridge: Harvard University Press, 1984.

[11] M. Adib, "Agen dan Struktur," J. Biokultur, vol. 1, no. 2, pp. 91-110, 2012.

[12] G. Ritzer and D. J. Goodman, Teori Sosiologi Modern. Jakarta: Kencana, 2004.

[13] T. S. Toomey, Communicating Across Cultures. New York: The Guilford Press, 1999.

[14] I. R. Adi, Redefinisi Pengkajian Amerika dalam Konteks Globalisasi (Pidato Pengukuhan Jabatan Guru Besar). Yogyakarta: Unpublished, 2015. 